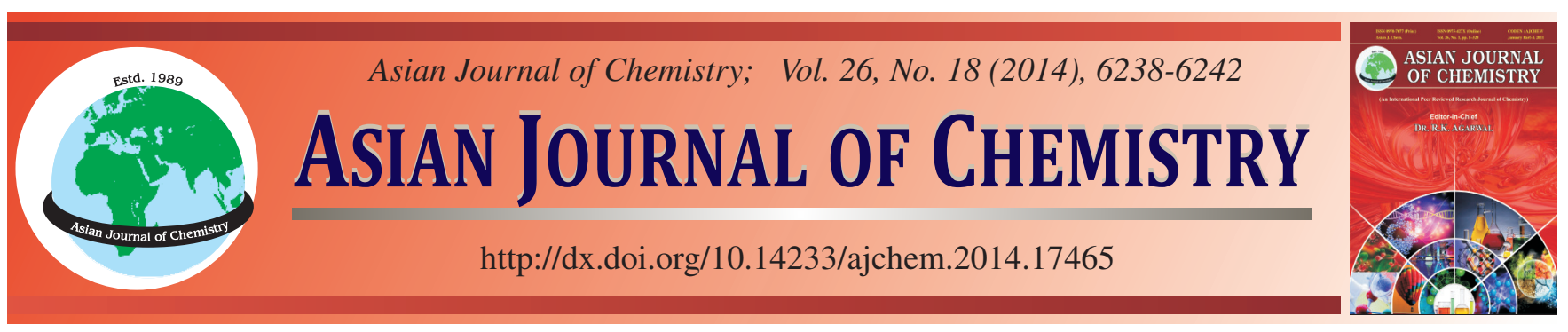

\title{
Potential Commercial Applications of Nano-Surfactant in Enhanced Oil: $\mathrm{Ni}_{0.5} \mathrm{Mn}_{0.5} \mathrm{Fe}_{2} \mathrm{O}_{4}$-Chitosan Nanoparticles
}

\author{
Q. LIAN and X.F. ZHENG ${ }^{*}$
}

College of Chemical Engineering, Hebei Normal University of Science and Technology, Qinhuangdao 066600, P.R. China

*Corresponding author: Tel: +86 24 2027029; E-mail: lianqilianqi517@163.com

\begin{abstract}
Chitosan nanoparticles with magnetic properties can be potentially used as separation materials in adsorption of oil for enhanced oil recovery. Different from the traditional surfactants, the novel magnetic $\mathrm{Ni}_{0.5} \mathrm{Mn}_{0.5} \mathrm{Fe}_{2} \mathrm{O}_{4}$-chitosan nanoparticles has the advantage of excellent biodegradation and a high level of controllability. The $\mathrm{Ni}_{0.5} \mathrm{Mn}_{0.5} \mathrm{Fe}_{2} \mathrm{O}$ 4-chitosan nanoparticles with core-shell structure was prepared successfully. The image of transmission electron microscope and the scanning electron microscopy showed that the cubic-shape magnetic $\mathrm{Ni}_{0.5} \mathrm{Mn}_{0.5} \mathrm{Fe}_{2} \mathrm{O}_{4}$ particles were encapsulated by the spherical chitosan nanoparticles. The size of the $\mathrm{Ni}_{0.5} \mathrm{Mn}_{0.5} \mathrm{Fe}_{2} \mathrm{O}_{4}$-chitosan nanoparticles were all below $100 \mathrm{~nm}$. The saturated magnetization of the $\mathrm{Ni}_{0.5} \mathrm{Mn}_{0.5} \mathrm{Fe}_{2} \mathrm{O}_{4}$-chitosan nanoparticles could reach 80 emu/g and showed the characteristics of superparamagnetism at the same time. The evaluation on the interfacial properties of the product showed that the interfacial tension between crude oil and water could be reduce to ultra-low values as low as $10^{-3} \mathrm{mN} / \mathrm{m}$ when the magnetic $\mathrm{Ni}_{0.5} \mathrm{Mn}_{0.5} \mathrm{Fe}_{2} \mathrm{O}_{4^{-}}$ chitosan nanoparticle was used in several blocks in Shengli Oilfield without other additives. Meanwhile, the magnetic $\mathrm{Ni}_{0.5} \mathrm{Mn}_{0.5} \mathrm{Fe}_{2} \mathrm{O}_{4^{-}}$ chitosan nanoparticles possessed good salt-resisting capacity.
\end{abstract}

Keywords: Magnetic nanoparticles, Surfactants, Superparamagnetism, Interfacial tension.

\section{INTRODUCTION}

Surface-active agents or surfactants are an important class of chemical compounds used in different sectors of modern industry, such as food, pharmaceutical, cosmetics and petroleum industries ${ }^{1,2}$. These compounds are able to reduce surface and interfacial tensions, as well as to form and stabilize oil in water or water in oil emulsions especially in adsorption of oil for enhanced oil recovery ${ }^{3}$. Currently, the alkyl benzene sulfonate ${ }^{4}$ is widely used in enhanced oil recovery which has serious pollution ${ }^{5}$, difficulty to recycling ${ }^{5}$ and non-directional movement ability. Due to environmental issues and artificial surfactant, the demand for biodegradable surfactants and controlling direction of the microemulsion with surfactants is increasing.

With the rapid development of nanotechnology, magnetic nanoparticles are currently being widely studied. Super-paramagnetic iron oxide nanoparticles have attracted researchers in various fields such as physics ${ }^{6}$ medicine ${ }^{7}$, biology ${ }^{8,9}$ and materials science ${ }^{10-13}$ due to their multifunctional properties such as small size, superparamagnetism and low toxicity. However, the nanoparticles tend to aggregate due to strong magnetic dipole-dipole attractions between particles. At the same time, the capacity for anti-acid, anti-alkali and anti-salt of magnetic nanoparticles is in the low level. Recently, the combination of organic and inorganic components at nano-sized level has attracted considerable attention because of the potential applications in many field ${ }^{14-16}$.

Chitosan is the alkaline deacetylated product of chitin which is derived from the exoskeleton of crustaceans. It is hydrophilic, biocompatible, non-toxic, biodegradable. Due to the presence of both hydroxyl and amine groups in its structure, chitosan can be chemically modified to be used as novel separation media ${ }^{17-19}$. So, chitosan and its derivative have been widely used in the field of medicine, pharmacy and biotechnology. Chang and $\mathrm{Chen}^{19}$ had prepared carboxmethylated magnetic particles by carboxmethylated the chitosan and bound onto $\mathrm{Fe}_{3} \mathrm{O}_{4}$ nanoparticles via carbodiimide activation. The carboxymethylated chitosan-conjugated $\mathrm{Fe}_{3} \mathrm{O}_{4}$ nanoparticles were shown to be quite efficient as anionic magnetic nano-adsorbent for the removal of acid dyes and heavy metal ions ${ }^{20-23}$. Here, we use chitosan as an effective stabilized agent for $\mathrm{Ni}_{0.5} \mathrm{Mn}_{0.5} \mathrm{Fe}_{2} \mathrm{O}_{4}$ nanoparticles and we test the ability to reduce the oil-water interfacial tension of the magnetic chitosan particles and the superparamagnetism which has the directional movement ability.

In this paper, magnetic $\mathrm{Ni}_{0.5} \mathrm{Mn}_{0.5} \mathrm{Fe}_{2} \mathrm{O}_{4}$-chitosan nanoparticles were obtained using $\mathrm{Ni}_{0.5} \mathrm{Mn}_{0.5} \mathrm{Fe}_{2} \mathrm{O}_{4}$ as cores and 
chitosan as a polymeric shell. The size, structure and magnetic properties of the resultant magnetic nanoparticles were characterized by TEM, SEM, XRD and vibrating sample magnetometer. The binding of chitosan to the magnetic nanoparticles was confirmed by Fourier transform infrared (FT-IR) spectroscopy. The performance of surface-active was measured by TX-500C full-scale automatic dynamic spinning drop interfacial tension instrument.

\section{EXPERIMENTAL}

Chitosan $\left(\mathrm{M}_{\mathrm{w}}=1 \times 10^{5}\right.$, deacetylating degree $\left.95.5 \%\right)$ were purchased from YuHuan Chemical Company, Zhejiang Province, China Glutaraldehyde solution (50\%), span-80, liquid paraffin, petroleum ether, ethanol, glacial acetic acid, sodium hydroxide $(\mathrm{NaOH})$, acetone, $\mathrm{Ni}_{0.5} \mathrm{Mn}_{0.5} \mathrm{Fe}_{2} \mathrm{O}_{4}$ (homemade).

Preparation of magnetic chitosan nanoparticles: According to mass ratio of $\mathrm{Ni}_{0.5} \mathrm{Mn}_{0.5} \mathrm{Fe}_{2} \mathrm{O}_{4}$ and chitosan is $1: 4$, $0.5 \mathrm{~g} \mathrm{Ni}_{0.5} \mathrm{Mn}_{0.5} \mathrm{Fe}_{2} \mathrm{O}_{4}$ magnetic particles was quickly added into the $40 \mathrm{~mL}$ acetic acid solution $(5 \% \mathrm{v} / \mathrm{v})$ which contained $2 \mathrm{~g}$ chitosan. The solution was placed in the ultrasonic reactor for $10 \mathrm{~min}$. At the same time, control the frequency of ultrasonic is $22 \mathrm{KHz}$ and the power is $1000 \mathrm{w}$ to dispersed the chitosan and the magnetic particles uniformly. After that, add $40 \mathrm{~mL}$ liquid paraffin and 10 drops of Span-80. Then the solution is placed in the ultrasonic reactor for $0.5 \mathrm{~h}$. In this work, the ultrasonic frequency is $22 \mathrm{KHz}$ and the power is $500 \mathrm{w}$. To active $\mathrm{Ni}_{0.5} \mathrm{Mn}_{0.5} \mathrm{Fe}_{2} \mathrm{O}_{4}$ for better magnetic properties, the reaction systems were kept at $60{ }^{\circ} \mathrm{C}$ for $5 \mathrm{~h}$ in a water bath. The cross-linked magnetic chitosan nanoparticles were formed by adding $2 \mathrm{~mL}$ of glutaraldehyde and by keeping the same condition for $5 \mathrm{~h}$. After reaction, the prepared nanoparticles was precipitated with centrifugation (8000 rpm for $1 \mathrm{~h}$ ) and rinsed with ethanol and deionized water for four times. Finally, the prepared nanoparticles were freeze dried for $24 \mathrm{~h}$.

Characterizations of magnetic chitosan nanoparticles: X-ray power diffraction (XRD) measurement was performed using a Bruker D8 diffractometer with monochromatized CuK $\alpha$ radiation $(\lambda=1.5426 \AA), 40 \mathrm{kV}, 30 \mathrm{~mA}$. Fourier transform infrared spectroscopy (FTIR, IRPrestige-21, Shimadzu Inc.) was used to conform the structure of the magnetic $\mathrm{Ni}_{0.5} \mathrm{Mn}_{0.5} \mathrm{Fe}_{2} \mathrm{O}_{4^{-}}$ chitosan nanoparticles. The magnetic chitosan nanoparticles were characterized by transmission electron microscope (TEM, $\mathrm{H}-7650$, Hitachi Inc.) to confirm the size and morphology .The sample of $\mathrm{Ni}_{0.5} \mathrm{Mn}_{0.5} \mathrm{Fe}_{2} \mathrm{O}_{4}$-chitosan nanoparticles for TEM analysis was obtained by placing a drop of the nanoparticle dispersed ethyl solution onto a copper micro-grid and evaporated in $20^{\circ} \mathrm{C}$. The surface of the magnetic particles is detected by the scanning electron microscope (SEM, Kyky-2800, Kyky technology Co., Ltd). The elemental analysis of the particles was analyzed by elemental analyzer (Vario EL III, Elementar Inc.). Magnetic measurement were done in a vibrating sample magnetometer (VSM, PPMS-9, Quantum Design). The sample power was placed in a Teflon-coated sample holder and the mass was accurately measured.

Determination of surface-active for products: The $\mathrm{Ni}_{0.5} \mathrm{Mn}_{0.5} \mathrm{Fe}_{2} \mathrm{O}_{4}$-chitosan nanoparticles were mixed with 100 $\mathrm{mL}$ injected water corresponding to the oil block. Put a drop crude oil (about $0.1 \mathrm{~mL}$ ) into the mixture and determine the oil-water interfacial tension.

The performance of surface-active depends on the activity to oil-water interface of the products. We use TX-500C fullscale automatic dynamic spinning drop interfacial tension instrument to measure the crude oil in GD-3, GD-4, GD-6,GD7 oil block from Shengli Oilfield in China after dehydrated and degassed. When injected water interfacial tension changed corresponding to time, the products should be able to reduce the oil-water interfacial tension to $10^{-3} \mathrm{mN} / \mathrm{m}$ and below without any other additives. Unless otherwise specified, the surfaceactive and anti-salt performance was tested in GD-3 from Shengli Oilfield in China after dehydrated and degassed corresponding to injected water. Furthermore, the products accounted for $0.4 \%$ of the injected water.

\section{RESULTS AND DISCUSSION}

FTIR: The curves a, b and $\mathrm{c}$ in Fig. 1 were the infrared spectroscopy of $\mathrm{Ni}_{0.5} \mathrm{Mn}_{0.5} \mathrm{Fe}_{2} \mathrm{O}_{4}$-chitosan nanoparticles, chitosan particles and the $\mathrm{Ni}_{0.5} \mathrm{Mn}_{0.5} \mathrm{Fe}_{2} \mathrm{O}_{4}$ particles. As can be seen from the curve a, there was a new absorption peak at $1635 \mathrm{~cm}^{-1}$ due to azomethine group. That indicated that the glutaraldehyde indeed involved in the cross-linking reaction. $580.5 \mathrm{~cm}^{-1}$ was a characteristic absorption peak of the magnetic $\mathrm{Ni}_{0.5} \mathrm{Mn}_{0.5} \mathrm{Fe}_{2} \mathrm{O}_{4}$ particles showed that $\mathrm{Ni}_{0.5} \mathrm{Mn}_{0.5} \mathrm{Fe}_{2} \mathrm{O} 4$ magnetic particles effectively crosslinked chitosan particles. In the curve b, between $3400-3200 \mathrm{~cm}^{-1}$ peaks were caused by stretching vibration of the $-\mathrm{OH}$ in chitosan and hydrogen bonding, between $3500-3400 \mathrm{~cm}^{-1}$ peaks were caused by the $\mathrm{N}-\mathrm{H}$ bond stretching vibration, the absorption peak near $2900 \mathrm{~cm}^{-1}$ was caused by $\mathrm{C}-\mathrm{H}$ bond stretching vibration, the absorption peak in $1617 \mathrm{~cm}^{-1}$ was caused by amide bond in chitosan, 1375 $\mathrm{cm}^{-1}$ was $\mathrm{CH}_{3}$ and $\mathrm{CH}_{2}$ absorption peaks. Curve $\mathrm{c}$ was an infrared spectrum of the $\mathrm{Ni}_{0.5} \mathrm{Mn}_{0.5} \mathrm{Fe}_{2} \mathrm{O}_{4}$ particles. Contrasting curves $\mathrm{a}, \mathrm{b}$ and $\mathrm{c}$ showed that: curve c contained all the characteristic peaks of the curve a and $b, \mathrm{Ni}_{0.5} \mathrm{Mn}_{0.5} \mathrm{Fe}_{2} \mathrm{O}_{4}$ magnetic particles were wrapped by chitosan particles successfully.

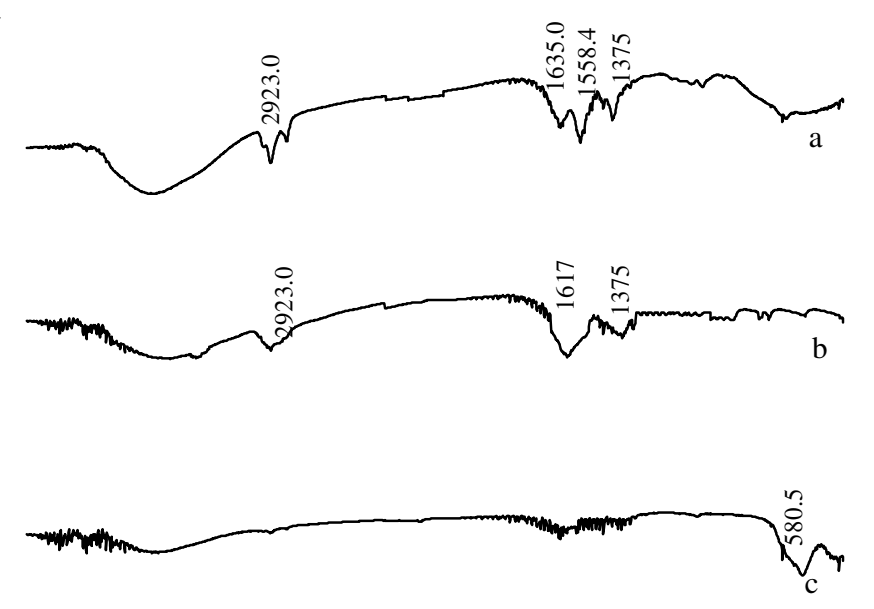

\begin{tabular}{|c|c|c|c|c|c|c|}
\hline 4000 & 3500 & 3000 & 2500 & 2000 & 1500 & 1000 \\
\hline
\end{tabular}

Fig. 1. FTIR spectra of samples:(a) $\mathrm{Ni}_{0.5} \mathrm{Mn}_{0.5} \mathrm{Fe}_{2} \mathrm{O}_{4}$-chitosan nanoparticles, (b) chitosan nanoparticles, (c) $\mathrm{Ni}_{0.5} \mathrm{Mn}_{0.5} \mathrm{Fe}_{2} \mathrm{O}_{4}$ particles 
XRD: All the diffraction peaks in Fig. 2 confirmed the component of the $\mathrm{Ni}_{0.5} \mathrm{Mn}_{0.5} \mathrm{Fe}_{2} \mathrm{O}_{4}$-chitosan nanoparticles. The $\mathrm{XRD}$ result of the magnetic chitosan particles and pure $\mathrm{Ni}_{0.5} \mathrm{Mn}_{0.5} \mathrm{Fe}_{2} \mathrm{O}_{4}$ particles were mostly coincident. The magnetic chitosan particles were validated as the binding of chitosan and $\mathrm{Ni}_{0.5} \mathrm{Mn}_{0.5} \mathrm{Fe}_{2} \mathrm{O}_{4}$.

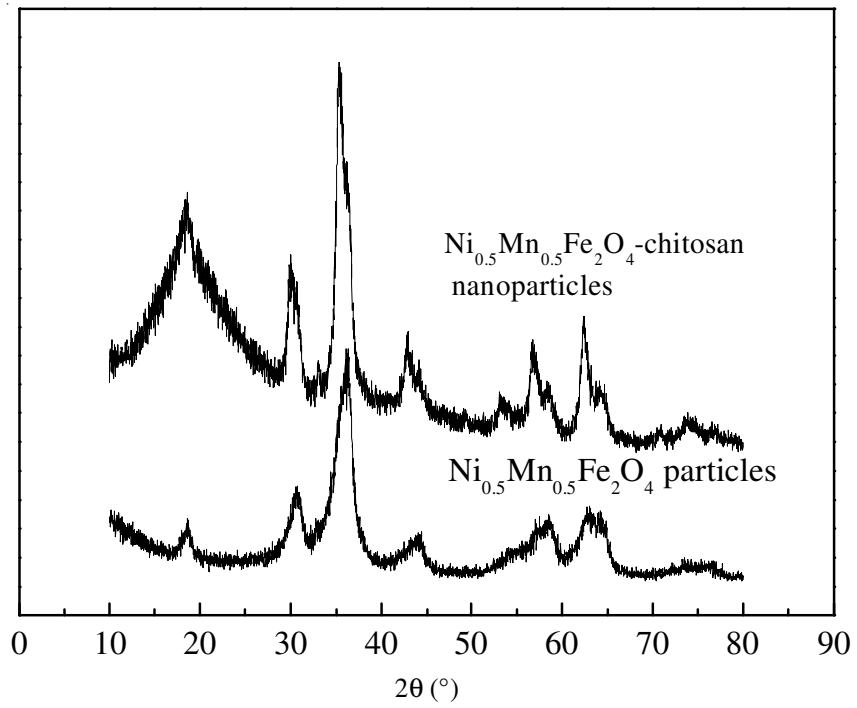

Fig. 2. XRD of cross-link magnetic chitosan nanoparticles

TEM: The TEM images of $\mathrm{Ni}_{0.5} \mathrm{Mn}_{0.5} \mathrm{Fe}_{2} \mathrm{O}_{4}$ particles (Fig. 3) and $\mathrm{Ni}_{0.5} \mathrm{Mn}_{0.5} \mathrm{Fe}_{2} \mathrm{O}_{4}$-chitosan nanoparticles particles (Fig. 4) showed the average diameter of the particles. The size of the $\mathrm{Ni}_{0.5} \mathrm{Mn}_{0.5} \mathrm{Fe}_{2} \mathrm{O}_{4}$ particles varied from 30 to $10 \mathrm{~nm}$. All of the $\mathrm{Ni}_{0.5} \mathrm{Mn}_{0.5} \mathrm{Fe}_{2} \mathrm{O}_{4}$ particles were with uniform distribution. Fig. 4 showed that all the magnetic chitosan particles were below $100 \mathrm{~nm}$.

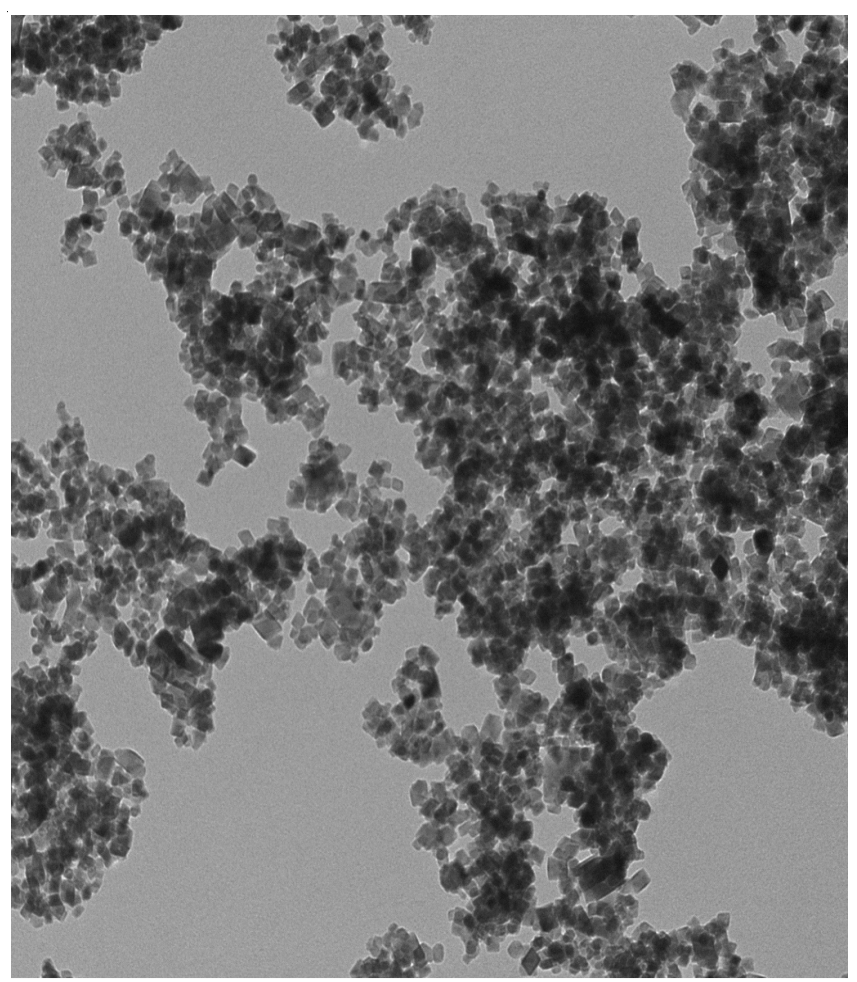

Fig. 3. TEM micrographs for the $\mathrm{Ni}_{0.5} \mathrm{Mn}_{0.5} \mathrm{Fe}_{2} \mathrm{O}_{4}$ particles

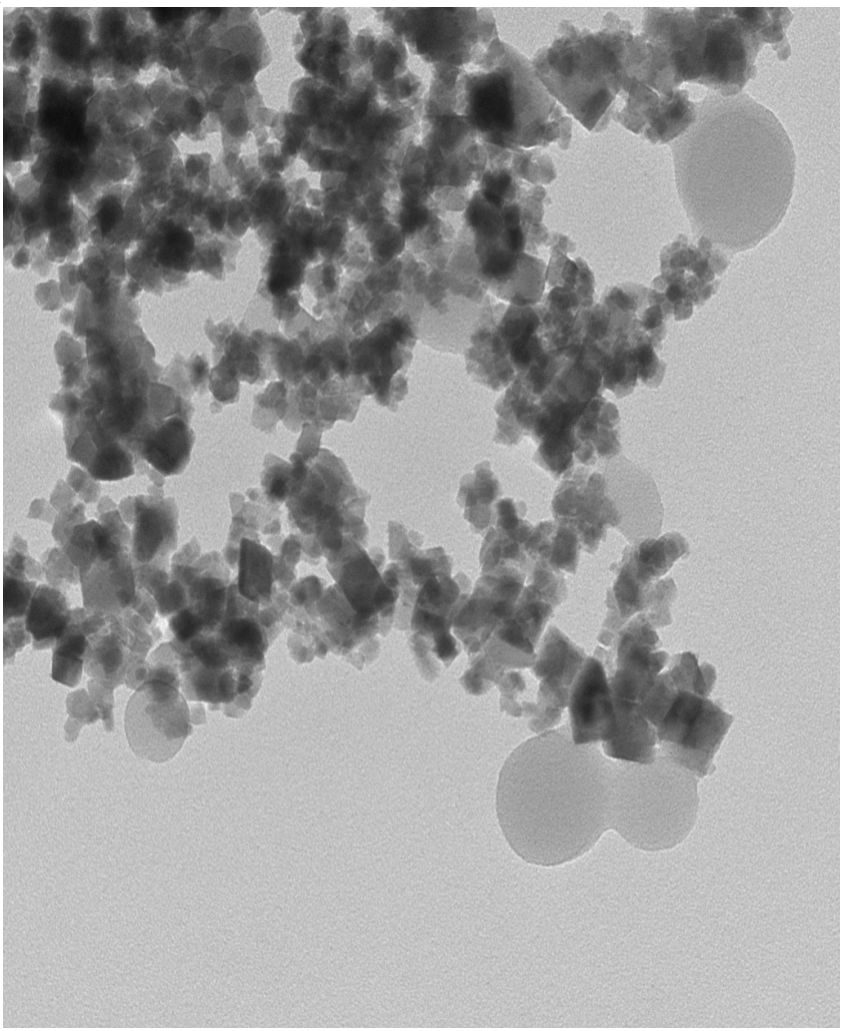

Fig. 4. TEM micrographs for the $\mathrm{Ni}_{0.5} \mathrm{Mn}_{0.5} \mathrm{Fe}_{2} \mathrm{O}_{4}$-chitosan nanoparticles

SEM: Figs. 5 and 6 showed the SEM images of the $\mathrm{Ni}_{0.5} \mathrm{Mn}_{0.5} \mathrm{Fe}_{2} \mathrm{O}_{4}$ particles and $\mathrm{Ni}_{0.5} \mathrm{Mn}_{0.5} \mathrm{Fe}_{2} \mathrm{O}_{4}$-chitosan nanoparticles. From Fig. 5, it is observed that the $\mathrm{Ni}_{0.5} \mathrm{Mn}_{0.5} \mathrm{Fe}_{2} \mathrm{O}_{4}$ particle was about $30 \mathrm{~nm}$ and have a spinel crystal structure. Fig. 6 showed the form of the magnetic chitosan nanoparticles. The diameter of the magnetic chitosan particles was about $60 \mathrm{~nm}$ and the form varied from the spinel structure of the $\mathrm{Ni}_{0.5} \mathrm{Mn}_{0.5} \mathrm{Fe}_{2} \mathrm{O}_{4}$ particle to egg-type shape. Fig. 6 confirms that the surface of magnetic CS particle was tightly wrapped and didn't have $\mathrm{Ni}_{0.5} \mathrm{Mn}_{0.5} \mathrm{Fe}_{2} \mathrm{O}_{4}$ particle. It indicated that the $\mathrm{Ni}_{0.5} \mathrm{Mn}_{0.5} \mathrm{Fe}_{2} \mathrm{O}_{4}$ particle was wrapped inside the chitosan successfully.

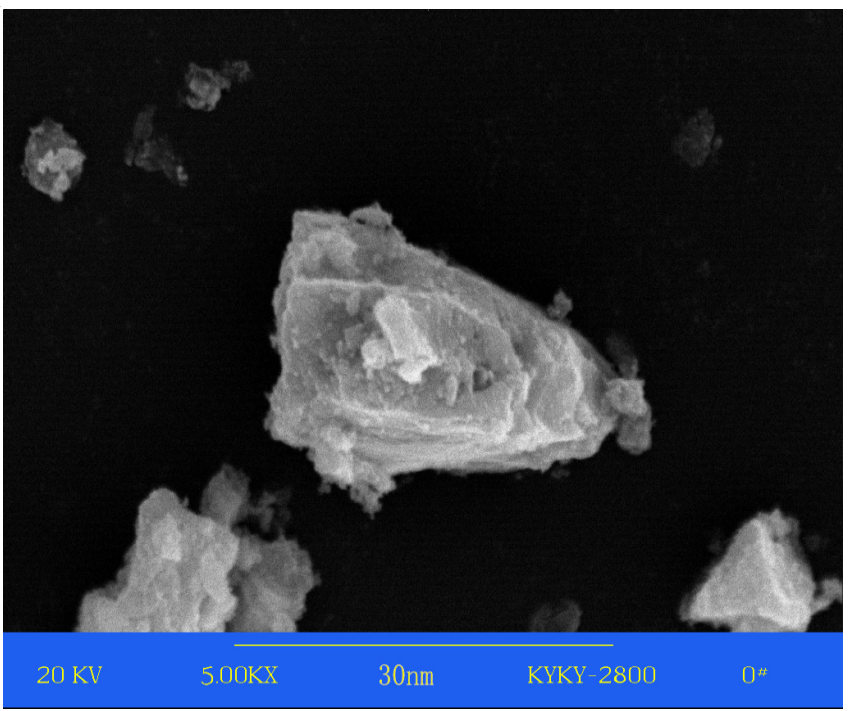

Fig. 5. SEM micrographs for the $\mathrm{Ni}_{0.5} \mathrm{Mn}_{0.5} \mathrm{Fe}_{2} \mathrm{O}_{4}$ particles 


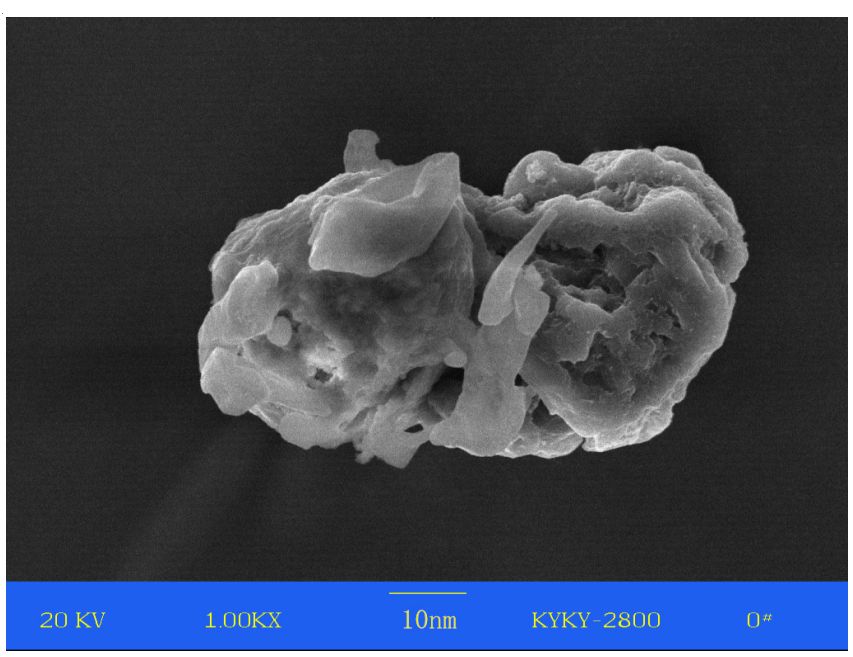

Fig. 6. SEM micrographs for the $\mathrm{Ni}_{0.5} \mathrm{Mn}_{0.5} \mathrm{Fe}_{2} \mathrm{O}_{4}$-chitosan nanoparticles

Elemental analysis: The data of elemental analysis in the Table- 1 shows the presence of $\mathrm{Ni}, \mathrm{Mn}, \mathrm{Fe}$, in the magnetic composite nanoparticles. The atoms ratio of $\mathrm{Fe}, \mathrm{Mn}, \mathrm{Ni}$ was about 4: 1: 1 and it indicated that $\mathrm{Ni}_{0.5} \mathrm{Mn}_{0.5} \mathrm{Fe}_{2} \mathrm{O}_{4}$ magnetic particles were encapsulated by chitosan particles integrally.

\begin{tabular}{ccccccc}
\multicolumn{7}{c}{ TABLE-1 } \\
\multicolumn{7}{c}{ ELEMENTAL ANALYSIS OF THE } \\
MAGNETIC CHITOSAN PARTICLES \\
\hline Element & $\mathrm{C}(\%)$ & $\mathrm{O}(\%)$ & $\mathrm{N}(\%)$ & $\mathrm{Ni}(\%)$ & $\mathrm{Mn}(\%)$ & $\mathrm{Fe}(\%)$ \\
\hline Content & 54.21 & 28.41 & 2.23 & 2.75 & 2.58 & 9.82 \\
\hline
\end{tabular}

Magnetization Test: For magnetic nanoparticles, one of the distinct behaviors is the occurrence of superparamagnetism which arises from thermal energy overcoming the magnetic anisotropy energy barriers of single domain particles. The difference between ferromagnetism and superparamagnetism is the particle size. The magnetic character of particle will change from multi-magnetic domain to mono-magnetic domain and its coercive force enhances with decrease of the scale of particles when the magnetic material is in nano-scale. When the diameter of particles is less than $30 \mathrm{~nm}$, the particles show the character of superparamagnetism ${ }^{24}$.

In Fig. 7, the magnetic properties of pure $\mathrm{Ni}_{0.5} \mathrm{Mn}_{0.5} \mathrm{Fe}_{2} \mathrm{O}_{4}$ particles and magnetic $\mathrm{Ni}_{0.5} \mathrm{Mn}_{0.5} \mathrm{Fe}_{2} \mathrm{O}_{4}$-chitosan nanoparticles were measured. The magnetization of the pure $\mathrm{Ni}_{0.5} \mathrm{Mn}_{0.5} \mathrm{Fe}_{2} \mathrm{O}_{4}$ particles was higher than that of the magnetic $\mathrm{Ni}_{0.5} \mathrm{Mn}_{0.5} \mathrm{Fe}_{2} \mathrm{O}_{4^{-}}$ chitosan nanoparticles. The magnetization of the pure $\mathrm{Ni}_{0.5} \mathrm{Mn}_{0.5} \mathrm{Fe}_{2} \mathrm{O}_{4}$ particles was high as $130 \mathrm{emu} / \mathrm{g}$ and that of the magnetic $\mathrm{Ni}_{0.5} \mathrm{Mn}_{0.5} \mathrm{Fe}_{2} \mathrm{O}_{4}$-chitosan nanoparticles was 80 $\mathrm{emu} / \mathrm{g}$, meanwhile both of the two particles showed the characteristics of superparamagnetism.

\section{Determination of surface-active properties}

Main properties of injected water: The density of the crude oil in GD-3, GD-4, GD-6,GD-7 oil block from Shengli Oilfield were $0.97,0.97,0.89$ and $0.91 \mathrm{~g} / \mathrm{mL}$. The main properties of the injected water for each block are shown in Table-2.

Determination of surface-active properties: We used the TX-500C full-scale automatic dynamic spinning drop interfacial tension instrument to determine the interfacial activity of the products on each oil block. When the measurement

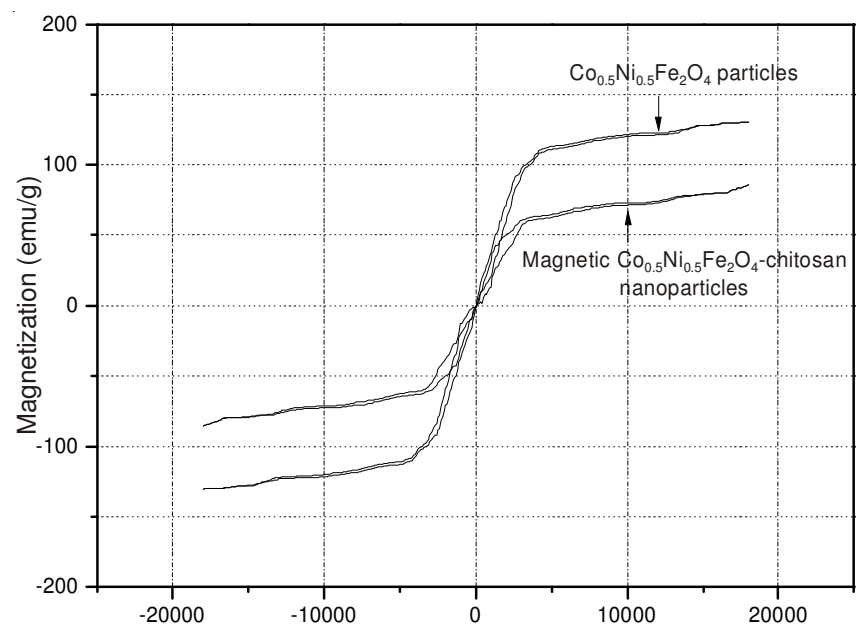

Fig. 7. Field dependence of magnetization for the $\mathrm{Ni}_{0.5} \mathrm{Mn}_{0.5} \mathrm{Fe}_{2} \mathrm{O}_{4}$-chitosan nanoparticles and $\mathrm{Ni}_{0.5} \mathrm{Mn}_{0.5} \mathrm{Fe}_{2} \mathrm{O}_{4}$ nanoparticles

TABLE-2

ION CONCENTRATION AND THE TOTAL MINERALIZATION OF THE WATER INTO GD OIL BLOCK

\begin{tabular}{ccccccc}
\hline \multirow{2}{*}{$\begin{array}{c}\text { Oil } \\
\text { block }\end{array}$} & \multicolumn{5}{c}{ Ion concentration $(\mathrm{mg} / \mathrm{L})$} \\
\cline { 2 - 7 } $\mathrm{Na}^{+}$ & $\mathrm{Ca}^{2+}$ & $\mathrm{Mg}^{2+}$ & $\mathrm{Cl}$ & $\mathrm{HCO}_{3}$ & $\begin{array}{c}\text { Total } \\
\text { mineralization }\end{array}$ \\
\hline GD-3 & 2995.8 & 207.2 & 125.9 & 4831 & 1437.8 & 9657.7 \\
GD-4 & 5164.2 & 320.8 & 156.8 & 10564 & 480 & 16685.8 \\
GD-6 & 9507.2 & 378.3 & 210 & 11186.2 & 599.1 & 21980.8 \\
GD-7 & 7414.1 & 213.2 & 268.3 & 8757.7 & 819.4 & 17472.7 \\
\hline
\end{tabular}

time was $1 \mathrm{~h}$, the results were shown in Fig. 8. It is clear from the Fig. 8 that the $\mathrm{Ni}_{0.5} \mathrm{Mn}_{0.5} \mathrm{Fe}_{2} \mathrm{O}_{4}$-chitosan nanoparticles reduced the oil-water interfacial tension to less than $10^{-3} \mathrm{mN} / \mathrm{m}$ in each oil bock without any additives. In particular, the products created minimum oil-water interfacial tension to $5.1 \times 10^{-4}$ $\mathrm{mN} / \mathrm{m}$ in GD-3 and GD-4 with similar nature. The time to reach a stable oil-water interface tension was short and it can reach the ideal interfacial tension value in 5 min generally. Fig. 8 also showed that the oil-water interfacial tension were stable. It indicated the products could form a stable flooding system with oil droplets.

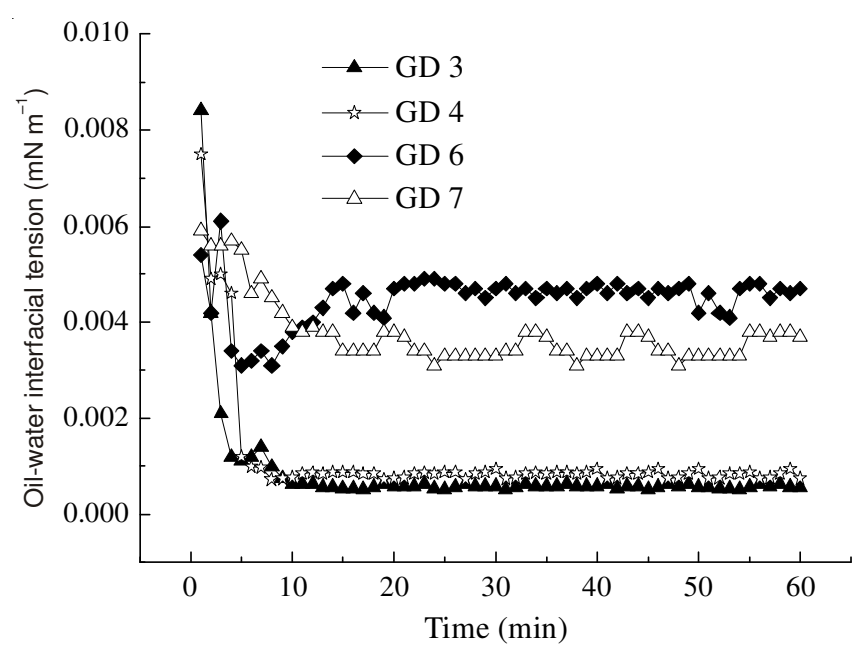

Fig. 8. Dynamic interfacial tension of GD oil block

Product concentration influence on oil-water interfacial tension: The impact of the $\mathrm{Ni}_{0.5} \mathrm{Mn}_{0.5} \mathrm{Fe}_{2} \mathrm{O}_{4}$-chitosan 
nanoparticles concentration to oil-water interfacial tension is shown in Fig. 9. Apparent from the Fig. 9, the percentage of products quality was $0.4 \%$ for its CMC point. When percentage of the products was above $0.25 \%$, the oil-water interfacial tension can reach $10^{-3} \mathrm{mN} / \mathrm{m}$. But a large number of micelles were formed in the solution when the products mass fraction is higher than $0.6 \%$. So continued to add products on the basis of the percentage of magnetic chitosan nanoparticles quality had little meaning.

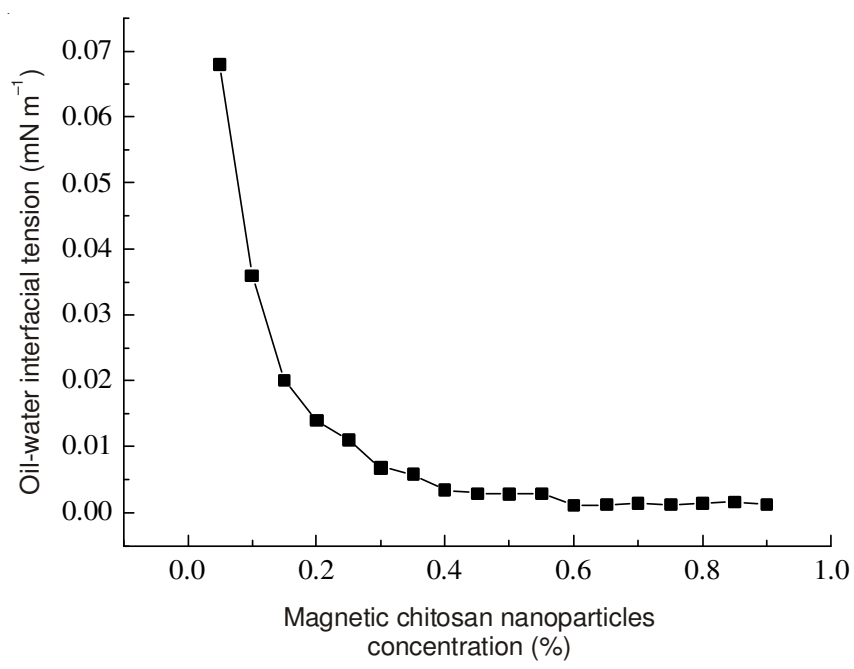

Fig. 9. Effects of $\mathrm{Ni}_{0.5} \mathrm{Mn}_{0.5} \mathrm{Fe}_{2} \mathrm{O}_{4}$-chitosan nanoparticles contents on the interfacial tension

Salt-resisting capacity: Because salinity of the injected water from different oil blocks varied widely and it affected the oil-water interfacial tension directly, the $\mathrm{Ni}_{0.5} \mathrm{Mn}_{0.5} \mathrm{Fe}_{2} \mathrm{O}_{4}$ chitosan nanoparticles must have good salt-resisting capacity. From the Fig. 10, we can see that the products could reduce oil-water interfacial tension to $10^{-3} \mathrm{mN} / \mathrm{m}$ or less when the $\mathrm{NaCl}$ concentration was $2500-17500 \mathrm{mg} / \mathrm{L}$.

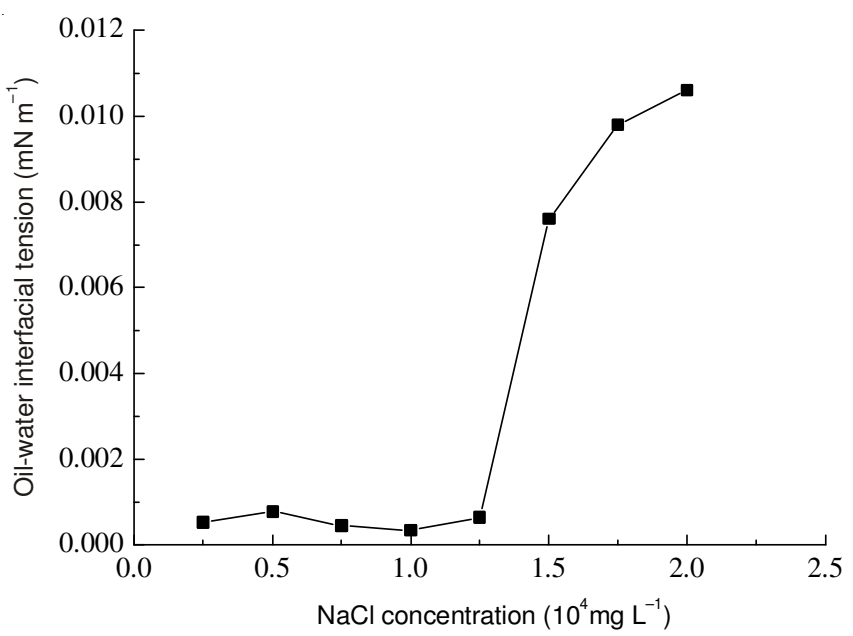

Fig. 10. Effect of $\mathrm{Na}^{+}$to interfacial tension

\section{Conclusion}

In summary, a novel $\mathrm{Ni}_{0.5} \mathrm{Mn}_{0.5} \mathrm{Fe}_{2} \mathrm{O}_{4}$-chitosan nanoparticles was composited with excellent core/shell structure and magnetic responsive properties. These super-paramagnetic $\mathrm{Ni}_{0.5} \mathrm{Mn}_{0.5} \mathrm{Fe}_{2} \mathrm{O}_{4^{-}}$ chitosan nanoparticles were able to reduce surface and interfacial tension to $10^{-3} \mathrm{mN} / \mathrm{m}$ and below without any other additives. The time to reach a stable oil-water interface tension was short and it can reach the ideal interfacial tension value in 5 min generally. At the same time, the $\mathrm{Ni}_{0.5} \mathrm{Mn}_{0.5} \mathrm{Fe}_{2} \mathrm{O}_{4}$-chitosan nanoparticles had good salt-resisting capacity.

\section{ACKNOWLEDGEMENTS}

This work was supported by Hebei Education Department Project (Q2012056) and Qinhuangdao Science and technology Bureau Project (2012021A127).

\section{REFERENCES}

1. I.M. Banat, R.S. Makkar and S.S. Cameotra, Appl. Microbiol. Biotechnol., 53, 495 (2000).

2. A. Singh, J.D. Van Hamme and O.P. Ward, Biotechnol. Adv., 25, 99 (2007).

3. J.D. Desai and I.M. Banat, Microbiol. Mol. Biol. Rev., 61, 47 (1997).

4. E. Carrero, N.V. Queipo, S. Pintos and L.E. Zerpa, J. Petrol. Sci. Eng., 58, 30 (2007)

5. M. Nitschke, S.G.V.A.O. Costa and J. Contiero, Biotechnol. Prog., 21, 1593 (2005).

6. S. Mukherjee, P. Das and R. Sen, Trends Biotechnol., 24, 509 (2006).

7. J.D. Van Hamme, A. Singh and O.P. Ward, Biotechnol. Adv., 24, 604 (2006).

8. R.S. Makkar, S.S. Cameotra and I.M. Banat, AMB Express, 1, 5 (2011).

9. H.-P. Meyer, Org. Process Res. Dev., 15, 180 (2011).

10. S.L. Fox and G.A. Bala, Bioresour. Technol., 75, 235 (2000).

11. L.R. Rodrigues, J.A. Teixeira and R. Oliveira, Biochem. Eng. J., 32, 135 (2006).

12. J. Roger, J.N. Pons, R. Massart, A. Halbreich and J. Bacri, Eur. Phys. J. Appl. Phys., 5, 321 (1999).

13. Y. Wu, J. Guo, W.L. Yang, C.C. Wang and S.K. Fu, Polymer, 47, 5287 (2006).

14. H.W. Gu, K.M. Xu, C.J. Xu and B. Xu, Chem. Commun., 941 (2006).

15. P. Wunderbaldinger, L. Josephson and R. Weissleder, Bioconjug. Chem., 13, 264 (2002).

16. W. Wang, L. Deng, Z.H. Peng and X. Xiao, Enzyme Microb. Technol., 40, 255 (2007).

17. W.S.W. Ngah, S. Ab Ghani and A. Kamari, Bioresour. Technol., 96, 443 (2005).

18. A.J. Varma, S.V. Deshpande and J.F. Kennedy, Carbohydr. Polym., 55, 77 (2004).

19. Y.C. Chang and D.H. Chen, J. Colloid Interf. Sci., 283, 446 (2005).

20. C. Shen, H. Chen, S. Wu, Y. Wen, L. Li, Z. Jiang, M. Li and W. Liu, J. Hazard. Mater., 244-245, 689 (2013).

21. A.C. Zimmermann, A. Mecabo, T. Fagundes and C.A. Rodrigues, J. Hazard. Mater., 179, 192 (2010).

22. R.B. Hernández, A.P. Franco, O.R. Yola, A. López-Delgado, J. Felcman, M.A.L. Recio and A.L.R. Mercê, J. Mol. Struct., 877, 89 (2008).

23. G. Zhao, J.J. Xu and H.Y. Chen, Electrochem. Commun., 8, 148 (2006).

24. L. Josephson, US Patent, 4,672,040 (1987). 